\title{
The Effect of Customer Perceived Value and E-Service Recovery One-Loyalty with E-Satisfaction and E-Trust as Intervening Variables on E-Commerce Shopee Indonesia Customers in Medan City
}

\author{
Dewi Kartika ${ }^{1}$, Amrin Fauzi ${ }^{2}$, Arlina Nurbaity Lubis ${ }^{3}$ \\ 1,2,3 Universitas Sumatera Utara, Medan, Indonesia \\ Corresponding Author: Dewi Kartika
}

\begin{abstract}
The rapid development of information and communication technology is currently having an impact on changes in various fields, one of which is changes in people's lifestyles, including consumption in society. The development of information and communication technology has resulted in easier access for people in the world to access the internet and use it to buying and selling transactions online via the internet. The report Global Web Index notes that Indonesia has a high level of users e-commerce highest in the world and as many as $96 \%$ of internet users looking for a product or service to make purchases online. This has resulted in the development of e-commerce in Indonesia and throughout the world which is increasing as a consequence of which the competition is getting harder service providers are e-commerce required to provide the best service in order to increase customer satisfaction and trust so that customers will be loyal to using these services. This can be achieved by paying attention to customer value and corrective actions in an effort to restore service to customers. The purpose of this study was to analyze the effect of customer perceived value and e-service recovery on e-loyalty with e-satisfaction and etrust as intervening variables. This study uses a quantitative approach by distributing questionnaires to ecommerce Shopee Indonesia customers in Medan City with a total sample of 328 respondents. The sampling technique in this study used non-probability sampling. Data
\end{abstract}

analysis was carried out through SEM-PLS using the SmartPLS program. The results of this study indicate that customer perceived value has a significant effect on e-satisfaction and also eloyalty. However, customer perceived value has no significant effect on e-trust. The variable eservice recovery directly has a significant effect on e-satisfaction, e-trust, and e-loyalty. Esatisfaction and e-trust cannot mediate the relationship between customer perceived value and e-loyalty, but they are able to mediate the relationship between e-service recovery and eloyalty.

Keywords: Customer perceived value, E-Service Recovery, E-Satisfaction, E-Trust, E-Loyalty

\section{INTRODUCTION}

This online shopping transaction is considered to make it easier for the community because it is able to provide a choice of how to shop for the community by not needing to come directly to the store, without the hassle of going through traffic jams to arrive at a shopping center, the desired item can be more easily obtained just by accessing the internet via a smartphone. This of course saves more time and energy. In addition, the increasing number of merchants selling goods through e-commerce platforms makes it easier for people to find and buy the goods they want. The Central Statistics Agency (2019) noted that during 2018 there were 24.8 million 
Dewi Kartika et.al. The Effect of customer perceived value and e-service recovery one-loyalty with esatisfaction and e-trust as intervening variables on e-commerce shopee Indonesia customers in Medan City.

online transactions with a transaction value of 17.21 trillion rupiah. www.statista.com said the number of e-commerce users in Indonesia will experience an increasing growth from 139 million dollars in 2017 to more than 212 million dollars in 2023. Likewise, Indonesia's e-commerce retail revenue is expected to increase more than six times from only 7.3 billion dollars in 2017 to 47.1 billion dollars in 2023. Based on these data, it shows that the e-commerce market in Indonesia is very prospective, it can be said that the Indonesian people have a consumptive nature and like to shop online considering this This is supported by the growing number of active internet users in Indonesia.

One of the companies in Indonesia that implements C2C e-commerce is Shopee. Shopee is an international ecommerce platform that first appeared in early 2015 in Singapore as the first mobile marketplace in Southeast Asia. With the rapid progress of the times, Shopee opened stores in Thailand, Vietnam, in Malaysia to meet the lifestyle needs of Southeast Asian men and women. Shopee started to enter the Indonesian market at the end of May 2015 and Shopee only started operating at the end of June 2015 in Indonesia to cater to the diverse lifestyles of consumers in Indonesia. Shopee is also present as a forum for sellers who sell all the needs of men and women, children, household needs, and other daily needs and make it easier for consumers in Indonesia to follow their lifestyle and fulfill their needs by using the products available at Shopee. Shopee is still the first mobile marketplace in Indonesia that offers the convenience of buying and selling directly on online buying and selling forums in Indonesia.

The purpose of this study is to develop a basic theoretical model and an empirical research model to fill the research gaps from previous studies. In this study, an empirical model will be developed and tested that pivots on customer perceived value and e-service recovery against e-trust, e-satisfaction and e-loyalty with conceptual objectives, as follows: 1. Analyzing the relationship and influence of customer perceived value on e-satisfaction on Shopee customers. 2. Analyze the relationship and influence of customer perceived value on etrust on Shopee customers. 3. Analyze the relationship and influence of customer perceived value on e-loyalty to Shopee customers. 4. Analyzing the relationship and effect of e-service recovery on satisfaction with Shopee customers. 5. Analyzing the relationship and effect of e-service recovery on e-trust on Shopee customers. 6. Analyze the relationship and direct effect of e-service recovery on e-loyalty to Shopee customers. 7. Analyze the relationship and influence of e-satisfaction on e-trust on Shopee customers. 8. Analyze the relationship and influence of e-satisfaction on e-loyalty to Shopee customers. 9. Analyze the relationship and influence of e-trust on eloyalty to Shopee customers. 10. Analyze the relationship and influence of customer perceived value on e-loyalty through esatisfaction and e-trust on Shopee customers. 11. Analyze the relationship and influence of e-service recovery value on loyalty through e-satisfaction and e-trust to Shopee customers.

\section{LITERATURE REVIEW E-Commerce}

E-commerce is the process of buying, selling, or trading data, goods, or services over the internet (Turban et al., 2015). E-commerce is defined as a commercial transaction involving the exchange of value through or using digital technology between individuals (Laudon and Traver, 2017). Media e-commerce involves using the internet, the world wide web, and applications or browsers on mobile or mobile devices to transact business. The mobile platform is the latest development in the Internet infrastructure of various mobile devices such as smartphones and tablets via a wireless network (wifi) or cellular telephone service. At the beginning of the development of e-commerce, the only digital media was a web browser, but 
Dewi Kartika et.al. The Effect of customer perceived value and e-service recovery one-loyalty with esatisfaction and e-trust as intervening variables on e-commerce shopee Indonesia customers in Medan City.

nowadays the more widely used media is through mobile applications (Laudon and Traver, 2017).

\section{E-Loyalty}

E-Loyalty Loyalty can be defined as a customer's intention to revisit and recommend an online vendor or continue to repurchase the vendor's products and services. Kim H.C et al., (2019). According to Kotler \& Keller, (2012) loyalty or loyalty is defined as a strongly held commitment to buy or subscribe to a particular product or service again in the future despite situational influences and marketing efforts that have the potential to cause behavior change. According to Lovelock and Wirtz (2011) the term loyalty has been used to describe the willingness of customers to continue to subscribe to a company in the long term, by buying and using its goods and services repeatedly and preferably exclusively, and voluntarily recommending the company's products. it to friends and colleagues. Consumer loyalty is defined based on two approaches, namely the behavioral approach and the attitude approach. Repeated purchases are the main indicator of consumer loyalty based on a behavioral approach (Kusuma et al., 2010).

\section{E-Loyalty Dimension}

In line with technological developments where more and more businesses are entering the online market, eloyalty is also becoming increasingly important (Kim et al., 2019). Thus, the subject of e-loyalty grows and develops an important topic for e-retailers. The concept of customer loyalty in online shopping needs to be measured to see the strength of the concept through the dimensions of the concept size. This is the point where the customer's cognitive evaluation is equated or even overpowered by the strong emotional and affective dynamics of the company-customer relationship.

\section{E-Satisfaction}

Satisfaction according to Kotler and Keller (2012), "satisfaction is a person's feeling of pleasure or disappointment that results from comparing a product or service's perceived performance (or outcome) to expectations". Satisfaction is a comparison between the expectations to be achieved and the performance obtained (Brilliant and Achyar, 2013). Dissatisfaction occurs when the perceived performance is less than expected. Satisfaction occurs when performance matches or exceeds expectations (Kotler et al., 2012). Satisfied consumers are consumers who tend to make repeat purchases, and recommend goods or services (Zeithaml et al., 2013).

\section{E-Trust}

The trust factor is a key factor of the many factors in every buying and selling online (Baskara and Hariyadi, 2014). Trust in an online site is known as e-trust. In the electronic business, trust is the consumer's trust in the quality and credibility of the goods and services provided by the online store. Trust is not something that can be recognized by other parties. Trust is defined as the perception of reliability from the consumer's point of view based on experience or the fulfillment of consumer expectations for the performance of certain products (Alexander, 2014).

\section{Costumer Perceived Value}

Kotler and Keller (2012) that customer perceived value is the difference between the evaluation of the customer's perspective on all benefits (benefits) and overall costs and compared with existing alternatives. According to Shabbir (2017) Perceived value is "a consumer's overall assessment of the utility of a product based on perceptions of what is received and what is given". According to Oesman (2010), the value expected by the customer is the difference between the customer's perception of the benefits of the product or service and the total cost to obtain it. Consumer value is the perceived value 
Dewi Kartika et.al. The Effect of customer perceived value and e-service recovery one-loyalty with esatisfaction and e-trust as intervening variables on e-commerce shopee Indonesia customers in Medan City.

during and/or after the use of a product (Rivière \& Mencarelli, 2012).

\section{E-Service Recovery}

Parasuraman, et al. (2005) define EService Recovery or often called electronic service quality recovery as a scale that measures the quality of electronic service recovery provided by E-commerce sites. Service recovery is defined as the specific actions that organizations need to take to ensure that customers get a solution after a service failure has caused them to be disappointed or dissatisfied. Service recovery is carried out to compensate for negative customer reactions to service failures (Situmorang \& Mulyono 2019).

\section{Dimensions of E-Service Recovery}

Justice theory has been used as the main basis in the development of a service recovery framework. In general, justice theory is represented by three dimensions, namely, procedural justice, interactional justice, and distributive justice (Kau and Loh, 2006).

\section{MATERIALS \& METHODS}

The type of research used in this research is associative/correlational research. The location of this research was conducted in the city of Medan. The time of this research is from July 2021 to September 2021. The population in this study are consumers who make online transactions on e-commerce Shopee Indonesia. The study will be tested on consumers in Medan City who have conducted transactions or shopped online at Shopee e-commerce. In this study, the researcher uses a nonprobability technique, where a sampling technique that does not provide equal opportunities/opportunities for each element or member of the population to be selected as a sample. The criteria that can be used as samples are Shopee e-commerce users in Medan City who have: a) At least 17 years old, b) made a minimum of 2 transactions c) used Shopee for a minimum of 3 months.

\section{RESULT \\ Description of Respondents \\ Characteristics \\ Characteristics of Respondents Based on Number of Transaction Activities}

Table 1. Characteristics Based on Number of Transaction

Activities
\begin{tabular}{|l|l|l|}
\hline $\begin{array}{l}\text { Number of } \\
\text { Transactions }\end{array}$ & $\begin{array}{l}\text { Frequency of } \\
\text { Respondents }\end{array}$ & Percentage \\
\hline 2 times & 58 & 17.6 \\
\hline $3-6$ times & 39 & 11.8 \\
\hline $7-10$ times & 50 & 15.3 \\
\hline 10 times & 181 & 55.3 \\
\hline Total Source: Research Results, 2021 (data processed) \\
\hline
\end{tabular}

Based on Table 4.1, it is known that there are 58 (17.6\%) respondents who make transactions at Shopee as much as 2 times, there are 39 (11.8\%) respondents who make transactions at Shopee as much as 3-6 times, there are $50(15.3 \%)$ respondents who made transactions at Shopee 7-10 times and there were 181 (55.3\%) respondents who made transactions at Shopee more than 10 times. Based on this data, it is known that there tend to be more respondents who have made transactions more than 10 times on Shopee e-commerce transactions. This shows that more shopee customers choose to routinely make online purchases again through Shopee e-commerce which is considered to be able to help ease their shopping needs.

Table 2: Characteristics of Respondents Based on Length of Use

\begin{tabular}{|l|l|l|}
\hline Usage Time & Frequency of Respondents & Percentage \\
\hline 3 Month & 35 & 10.6 \\
\hline 4-8 Month & 35 & 10.6 \\
\hline 9-12 Month & 31 & 9.4 \\
\hline More Than 1 Year & 228 & 69.4 \\
\hline Total & 328 & 100.0 \\
\hline
\end{tabular}

Source: Research Results, 2021 (data processed)

Based on Table 2, it is known that there are 35 (10.6\%) respondents who have used Shopee within 3 months, there are 35 (10.6\%) respondents who have used Shopee within 4-8 months, there are 31 (9.4\%) respondents who have used Shopee for a period of 9-12 months and there are 228 (69.4\%) respondents who have used Shopee for more than 1 year. Based on this data, it is known that there tend to be more respondents who have subscribed to using Shopee for more than 1 year. This shows 
Dewi Kartika et.al. The Effect of customer perceived value and e-service recovery one-loyalty with esatisfaction and e-trust as intervening variables on e-commerce shopee Indonesia customers in Medan City.

that more Shopee customers choose to stay with the services of Shopee e-commerce.

Tabel 3: Characteristics of Respondents Based on Transaction Value

\begin{tabular}{|l|l|l|}
\hline Transaction Value & $\begin{array}{l}\text { Frequency of } \\
\text { Respondents }\end{array}$ & Percentage \\
\hline Less than IDR 50,000 & 8 & 2.4 \\
\hline Rp 50.000 - Rp 150.000 & 73 & 22.4 \\
\hline Rp 151.000 - Rp 300.000 & 92 & 28.2 \\
\hline Rp 301.000 - Rp 500.000 & 85 & 25.9 \\
\hline More than IDR 500,000 & 70 & 21.2 \\
\hline Total & 328 & 100.0 \\
\hline
\end{tabular}

Source: Research Results, 2021 (data processed)

Based on Table 3 , it is known that there are 8 (2.4\%) respondents whose highest transaction value shopping at Shopee is only less than Rp. 50,000, there are $73(22.4 \%)$ respondents whose highest transaction value shopping at Shopee is in the range of Rp. 50,000 - Rp. 150,000, there are $92(28.2 \%)$ respondents with the highest transaction value shopping at Shopee are in the range of Rp. 151,000 - Rp. 300,000 and there are 85 (25.9\%) respondents whose highest transaction value is shopping at Shopee in the range of Rp. 301,000 - Rp. 500,000 and there are 70 (21.2\%) respondents with the highest transaction value shopping at Shopee are in the range of more than IDR 500,000. Based on these data, it is known that the highest transaction value tends to be in the range of $\mathrm{Rp}$. 150,000 - Rp. 300,000. This shows that there are many respondents who are willing to make transactions at Shopee with a value of hundreds of thousands of rupiah, and not even a few whose transaction value exceeds Rp. 500,000.

\section{Distribution of Respondents' Answers}

\begin{tabular}{|c|c|c|c|c|c|c|c|c|c|c|c|c|c|}
\hline \multirow[t]{2}{*}{ Dimensi } & \multirow[t]{2}{*}{$\mathbf{P}$} & \multicolumn{2}{|c|}{ STS } & \multicolumn{2}{|l|}{ TS } & \multicolumn{2}{|l|}{ KS } & \multicolumn{2}{|l|}{$\mathrm{S}$} & \multicolumn{2}{|l|}{ SS } & \multirow[t]{2}{*}{ Mean } & \multirow[t]{2}{*}{ Kategori } \\
\hline & & f & $\%$ & f & $\%$ & $\mathbf{F}$ & $\%$ & f & $\%$ & f & $\%$ & & \\
\hline \multirow[t]{2}{*}{ EmotionalValue } & CPV1 & 0 & 0,00 & 20 & 6,10 & 16 & 4,88 & 192 & 58,54 & 100 & 30,49 & 4,13 & Well \\
\hline & CPV2 & 0 & 0,00 & 16 & 4,88 & 12 & 3,66 & 204 & 62,20 & 96 & 29,27 & 4,16 & Well \\
\hline \multirow[t]{2}{*}{ SocialValue } & CPV3 & 0 & 0,00 & 20 & 6,10 & 104 & 31,71 & 131 & 39,94 & 73 & 22,26 & 3,78 & Well \\
\hline & CPV4 & 4 & 1,22 & 16 & 4,88 & 24 & 7,32 & 176 & 53,66 & 108 & 32,93 & 4,12 & Well \\
\hline \multirow[t]{2}{*}{ Price Value } & CPV5 & 0 & 0,00 & 16 & 4,88 & 32 & 9,76 & 192 & 58,54 & 88 & 26,83 & 4,07 & Well \\
\hline & CPV6 & 0 & 0,00 & 20 & 6,10 & 56 & 17,07 & 144 & 43,90 & 108 & 32,93 & 4,04 & Well \\
\hline \multirow[t]{2}{*}{ Performancevalue } & CPV7 & 0 & 0,00 & 24 & 7,32 & 8 & 2,44 & 164 & 50,00 & 132 & 40,24 & 4,23 & Very Well \\
\hline & CPV8 & 4 & 1,22 & 20 & 6,10 & 24 & 7,32 & 196 & 59,76 & 84 & 25,61 & 4,02 & Well \\
\hline
\end{tabular}

Information:

Source: Research Results, 2021 (data processed)

CPV1 = Shopping online using Shopee e-commerce makes me feel happy

CPV2 = Shopping online through Shopee e-commerce makes me feel comfortable.

CPV3 = Using Shopee e-commerce can add new friends.

CPV4 = Using Shopee e-commerce can add reference groups for the desired product.

CPV5 = The price value offered by Shopee e-commerce is in accordance with the expected quality.

CPV6 = The price value offered by Shopee e-commerce is cheaper than competitors

CPV7 = Using Shopee's e-commerce services can make shopping easier

$C P V 8=$ The services provided by Shopee e-commerce are as I expected

Table 5: Distribution of Answers to E-Service Recovery Variables (X2)

\begin{tabular}{|c|c|c|c|c|c|c|c|c|c|c|c|c|c|}
\hline \multirow{3}{*}{ Dimensi } & & & & & & & & & & & & & \\
\hline & \multirow[t]{2}{*}{$\mathbf{P}$} & \multicolumn{2}{|c|}{ STS } & \multicolumn{2}{|c|}{ TS } & \multicolumn{2}{|c|}{ KS } & \multicolumn{2}{|l|}{$\mathrm{S}$} & \multicolumn{2}{|l|}{ SS } & \multirow[t]{2}{*}{ Mean } & \multirow[t]{2}{*}{ Kategori } \\
\hline & & $\mathbf{F}$ & $\%$ & $\mathbf{F}$ & $\%$ & $\mathbf{F}$ & $\%$ & $\mathbf{F}$ & $\%$ & $\mathbf{F}$ & $\%$ & & \\
\hline \multirow{3}{*}{$\begin{array}{l}\text { Procedur al } \\
\text { Justice }\end{array}$} & SR1 & 0 & 0,00 & 12 & 3,66 & 40 & 12,20 & 168 & 51,22 & 108 & 32,93 & 4,13 & Well \\
\hline & SR2 & 0 & 0,00 & 12 & 3,66 & 36 & 10,98 & 192 & 58,54 & 88 & 26,83 & 4,09 & Well \\
\hline & SR3 & 0 & 0,00 & 12 & 3,66 & 32 & 9,76 & 192 & 58,54 & 92 & 28,05 & 4,11 & Well \\
\hline \multirow{4}{*}{$\begin{array}{l}\text { Interactio nal } \\
\text { Justice }\end{array}$} & SR4 & 0 & 0,00 & 8 & 2,44 & 36 & 10,98 & 188 & 57,32 & 96 & 29,27 & 4,13 & Well \\
\hline & SR5 & 0 & 0,00 & 8 & 2,44 & 24 & 7,32 & 180 & 54,88 & 116 & 35,37 & 4,23 & Very Well \\
\hline & SR6 & 0 & 0,00 & 8 & 2,44 & 24 & 7,32 & 208 & 63,41 & 88 & 26,83 & 4,15 & Well \\
\hline & SR7 & 0 & 0,00 & 8 & 2,44 & 24 & 7,32 & 200 & 60,98 & 96 & 29,27 & 4,17 & Well \\
\hline \multirow{2}{*}{$\begin{array}{l}\text { Distributi ve } \\
\text { Justice }\end{array}$} & SR8 & 0 & 0,00 & 4 & 1,22 & 44 & 13,41 & 180 & 54,88 & 100 & 30,49 & 4,15 & Well \\
\hline & SR9 & 0 & 0,00 & 12 & 3,66 & 56 & 17,07 & 188 & 57,32 & 72 & 21,95 & 3,98 & Well \\
\hline
\end{tabular}

Information:

SR1 = Shopee handles customer complaints well

SR2 = Shopee provides the right solution for customer complaints

SR3 = Shopee is quick to respond to customer complaints

SR4 = Shopee provides a good explanation to customers regarding service failures that occur

SR5 = Shopee is polite in responding to customer complaints

SR6 = Shopee has tried its best to fix the errors that occurred

SR7 $\quad$ Shopee cares about customers

SR8 = Shopee provides solutions according to customer needs.

SR9 = Shopee is pleased to provide compensation to customers who commensurate with the losses suffered 
Dewi Kartika et.al. The Effect of customer perceived value and e-service recovery one-loyalty with esatisfaction and e-trust as intervening variables on e-commerce shopee Indonesia customers in Medan City.

Based on Table 4 the distribution of respondents' answers to the Customer Perceived Value variable above, it can be concluded that the first highest value in the CPV7 statement (using Shopee e-commerce services can make shopping easier) with an average value of 4.23 in the very good category. While the lowest value in this study is in the CPV8 statement (the service provided by Shopee e-commerce is as I expected) with a value of 4.02 which is still in the good category.

Based on Table 5 the distribution of respondents' answers to the $E$ Satisfaction variable above, it can be concluded that the highest value in the SR5 statement (Shopee is polite in responding to customer complaints)

\begin{tabular}{|c|c|c|c|c|c|c|c|c|c|c|c|c|c|}
\hline \multirow[t]{2}{*}{ Dimension } & \multirow[t]{2}{*}{$\mathbf{P}$} & \multicolumn{2}{|c|}{ STS } & \multicolumn{2}{|l|}{ TS } & \multicolumn{2}{|c|}{ KS } & \multicolumn{2}{|l|}{$\mathrm{S}$} & \multicolumn{2}{|l|}{ SS } & \multirow[t]{2}{*}{ Mean } & \multirow[t]{2}{*}{ Category } \\
\hline & & $\mathbf{F}$ & $\%$ & $\mathbf{F}$ & $\%$ & $\mathbf{F}$ & $\%$ & $\mathbf{F}$ & $\%$ & $\mathbf{F}$ & $\%$ & & \\
\hline \multirow[t]{2}{*}{ Convenience } & SFT1 & 0 & 0,00 & 12 & 3,66 & 20 & 6,10 & 192 & 58,54 & 104 & 31,71 & 4,18 & Well \\
\hline & SFT2 & 0 & 0,00 & 8 & 2,44 & 28 & 8,54 & 176 & 53,66 & 116 & 35,37 & 4,22 & Very Well \\
\hline \multirow[t]{2}{*}{ Mechandising } & SFT3 & 0 & 0,00 & 8 & 2,44 & 16 & 4,88 & 224 & 68,29 & 80 & 24,39 & 4,15 & Well \\
\hline & SFT4 & 0 & 0,00 & 8 & 2,44 & 60 & 18,29 & 184 & 56,10 & 76 & 23,17 & 4,00 & Well \\
\hline \multirow[t]{2}{*}{ Site design } & SFT5 & 4 & 1,22 & 0 & 0,00 & 28 & 8,54 & 176 & 53,66 & 120 & 36,59 & 4,24 & Very Well \\
\hline & SFT6 & 0 & 0,00 & 8 & 2,44 & 20 & 6,10 & 172 & 52,44 & 128 & 39,02 & 4,28 & Very Well \\
\hline \multirow[t]{2}{*}{ Security } & SFT7 & 0 & 0,00 & 8 & 2,44 & 24 & 7,32 & 196 & 59,76 & 100 & 30,49 & 4,18 & Well \\
\hline & SFT8 & 0 & 0,00 & 4 & 1,22 & 20 & 6,10 & 196 & 59,76 & 108 & 32,93 & 4,24 & Very Well \\
\hline \multirow[t]{2}{*}{ Serviceability } & SFT9 & 0 & 0,00 & 8 & 2,44 & 36 & 10,98 & 108 & 32,93 & 176 & 53,66 & 4,38 & Very Well \\
\hline & SFT10 & 4 & 1,22 & 8 & 2,44 & 24 & 7,32 & 136 & 41,46 & 156 & 47,56 & 4,32 & Very Well \\
\hline
\end{tabular}

Information:

SFT1 = Happy to enjoy online shopping activities using e-commerce Shopee.

SFT2 = It's easy to find any desired product on Shopee e-commerce.

SFT3 = Happy with the information provided by Shopee e-commerce is quite relevant to what consumers receive.

SFT4 = Happy to see the products presented on Shopee are as expected.

SFT5 = Happy with the uncomplicated search path on Shopee.

SFT6 = Happy with the appearance of the menu from Shopee e-commerce neatly arranged.

SFT7 = Happy with the confidentiality of personal data at Shopee which is well maintained.

SFT8 = Happy with the guaranteed transaction security.

SFT9 = Happy with the free shipping service provided by Shopee.

SFT10 = Happy with the promotions given by Shopee every month

Based on Table 6, the distribution of respondents' answers to the E-Satisfaction variable above, it can be concluded that the highest score on the SFT9 statement (happy with the free shipping service provided by Shopee) with a value of 4.38 is a very good category. While the lowest score in this study is in the statement of SFT7 (pleased with the confidentiality of personal data at Shopee which is well maintained) with a value of 4.18 which is still in the good category.

Table 7: Distribution of Answers to E-Trust Variables (Z2)

\begin{tabular}{|c|c|c|c|c|c|c|c|c|c|c|c|c|c|}
\hline \multirow[t]{2}{*}{ Dimension } & \multirow[t]{2}{*}{$\mathbf{P}$} & \multicolumn{2}{|c|}{ STS } & \multicolumn{2}{|c|}{ TS } & \multicolumn{2}{|c|}{ KS } & \multicolumn{2}{|l|}{$\mathrm{S}$} & \multicolumn{2}{|c|}{ SS } & \multirow[t]{2}{*}{ Mean } & \multirow[t]{2}{*}{ Category } \\
\hline & & $\mathbf{F}$ & $\%$ & $\mathbf{F}$ & $\%$ & $\mathbf{F}$ & $\%$ & $\mathbf{F}$ & $\%$ & $\mathbf{F}$ & $\%$ & & \\
\hline \multirow{3}{*}{ Benevolence } & TR1 & 0 & 0,00 & 0 & 0,00 & 28 & 8,54 & 208 & 63,41 & 92 & 28,05 & 4,20 & Very Well \\
\hline & TR2 & 0 & 0,00 & 0 & 0,00 & 24 & 7,32 & 224 & 68,29 & 80 & 24,39 & 4,17 & Well \\
\hline & TR3 & 0 & 0,00 & 0 & 0,00 & 28 & 8,54 & 220 & 67,07 & 80 & 24,39 & 4,16 & Well \\
\hline \multirow[t]{2}{*}{ Integrity } & TR4 & 0 & 0,00 & 4 & 1,22 & 36 & 10,98 & 208 & 63,41 & 80 & 24,39 & 4,11 & Well \\
\hline & TR5 & 0 & 0,00 & 0 & 0,00 & 16 & 4,88 & 236 & 71,95 & 76 & 23,17 & 4,18 & Well \\
\hline \multirow{3}{*}{ Competence } & TR6 & 0 & 0,00 & 0 & 0,00 & 12 & 3,66 & 232 & 70,73 & 84 & 25,61 & 4,22 & Very Well \\
\hline & TR7 & 0 & 0,00 & 0 & 0,00 & 16 & 4,88 & 216 & 65,85 & 96 & 29,27 & 4,24 & Very Well \\
\hline & TR8 & 0 & 0,00 & 0 & 0,00 & 20 & 6,10 & 220 & 67,07 & 88 & 26,83 & 4,21 & Sangat Baik \\
\hline
\end{tabular}

Information:

TR1 = I believe Shopee will be responsible to its customers.

TR2 = I believe Shopee will accept every customer complaint

TR3 = I believe Shopee will sincerely accept customer input

TR4 = I believe Shopee provides correct information according to facts

TR5 = I believe Shopee will fulfill the agreement made to the customer.

TR6 = I believe Shopee has good knowledge of securing transactions.

TR7 = I believe Shopee is able to meet customer needs.

TR8 = I believe Shopee is able to provide good service to customer 
Dewi Kartika et.al. The Effect of customer perceived value and e-service recovery one-loyalty with esatisfaction and e-trust as intervening variables on e-commerce shopee Indonesia customers in Medan City.

Based on Table 7 the distribution of respondents' answers to the E-Trust variable above, it can be concluded that the highest value in the TR6 statement (I believe Shopee has good knowledge of securing transactions) with a value of 4.22 is a very good category. While the lowest value in this study is in the TR4 statement (I believe Shopee provides correct information according to facts) with a value of 4.11 which is still in the good category.

Table 8: Distribution of Answers to Variable E-Loyalty (Y)

\begin{tabular}{|c|c|c|c|c|c|c|c|c|c|c|c|c|c|}
\hline \multirow{2}{*}{ Dimension } & \multirow[b]{2}{*}{$\mathbf{P}$} & \multicolumn{2}{|c|}{ STS } & \multicolumn{2}{|l|}{ TS } & \multicolumn{2}{|l|}{ KS } & \multicolumn{2}{|l|}{$\mathbf{S}$} & \multicolumn{2}{|l|}{ SS } & \multirow[b]{2}{*}{ Mean } & \multirow[b]{2}{*}{ Category } \\
\hline & & f & $\%$ & $\mathbf{F}$ & $\%$ & $\mathbf{F}$ & $\%$ & f & $\%$ & $\mathbf{F}$ & $\%$ & & \\
\hline \multirow[t]{2}{*}{ Preference } & LY1 & 0 & 0,00 & 0 & 0,00 & 56 & 17,07 & 152 & 46,34 & 120 & 36,59 & 4,20 & Sangat Baik \\
\hline & LY2 & 0 & 0,00 & 0 & 0,00 & 80 & 24,39 & 156 & 47,56 & 92 & 28,05 & 4,04 & Baik \\
\hline \multirow[t]{2}{*}{ Patronage } & LY3 & 0 & 0,00 & 4 & 1,22 & 8 & 2,44 & 228 & 69,51 & 88 & 26,83 & 4,22 & Sangat Baik \\
\hline & LY4 & 0 & 0,00 & 0 & 0,00 & 20 & 6,10 & 204 & 62,20 & 104 & 31,71 & 4,26 & Sangat Baik \\
\hline \multirow[t]{2}{*}{ Premium } & LY5 & 0 & 0,00 & 0 & 0,00 & 100 & 30,49 & 160 & 48,78 & 68 & 20,73 & 3,90 & Baik \\
\hline & LY6 & 12 & 3,66 & 28 & 8,54 & 140 & 42,68 & 100 & 30,49 & 48 & 14,63 & 3,44 & Baik \\
\hline
\end{tabular}

Source: Research Results, 2021 (data processed)

Information:

LY1 = I make Shopee E-commerce my first choice every time I want to shop online.

$L Y 2$ = I feel Shopee's E-commerce is the best compared to other e-commerce brands.

$L Y 3=I$ am willing to give a positive rating on Shopee e-commerce.

LY4 = I am willing to recommend Shopee e-commerce to others.

LY5 = I keep coming back to make purchases no matter what happens on Shopee's e-commerce.

LY6 = I have no interest in making purchases from other e-commerce brands

Based on Table 8 the distribution of respondents' answers to the E-Loyalty variable above, it can be concluded that the highest value in the LY4 statement (I am willing to recommend Shopee e-commerce to others) with a value of 4.26 is a very good category. While the lowest value in this study is in the statement of LY6 (I am not interested in making purchases at other e-commerce brands) with a value of 3.44 which is still in the good category.

\section{DISCUSSION}

\section{The Influence of Customer Perceived Value on E-Satisfaction}

Based on the results of the direct influence hypothesis test for hypothesis one, it is known that customer perceived value has a significant effect on e-satisfaction, where the coefficient value obtained is 0.495 with a significant value of 0.000 $<0.05$, which means that customer perceived value has a significant effect on esatisfaction. Satisfied consumers are customers who feel they get value from producers or service providers. Based on the explanation above, it can be interpreted that if the customer during or after using the product/service from the provider, and the customer gets or feels the value and benefits that are considered good and in accordance with the customer's expectations, what happens is that the customer will feel happy and satisfied. As perceived by Shopee customers, it can be seen from the distribution of respondents' answers in Table 4 that customers get benefits and a good experience when shopping using Shopee e-commerce, as seen from the average value of each statement in the good category. In the dimension of emotional value, namely customers feel happy and more comfortable when shopping, then in terms of social value customers can add reference groups and some feel they can add friendship, then also in terms of price value customers feel that the price offered is in accordance with the quality and is also cheaper than competitors, and also in terms of performance value, customers find it easier to shop and get services as expected, so these things can affect customer satisfaction when using Shopee services. This means that if a company can create a good customer perception value, it will increase customer satisfaction. It is therefore important for companies to understand the perceived and expected value of their customers. Based on the results of research on Shopee customers related to the 
Dewi Kartika et.al. The Effect of customer perceived value and e-service recovery one-loyalty with esatisfaction and e-trust as intervening variables on e-commerce shopee Indonesia customers in Medan City.

measurement of the customer perceived value variable, which can be seen in Table 5 , it was found that the lowest statistical calculation value lies in the social value dimension, this means that Shopee needs to pay attention to and further increase perceived social values. by customers to help increase customer value and increase satisfaction for customers who use Shopee services.

\section{The Influence of Customer Perceived Value on E-Trust.}

Based on the results of the direct effect hypothesis test for the second hypothesis, it is known that customer perceived value has no significant effect on e-trust, where the coefficient value is 0.005 with a significant value of $0.959>0.05$, which means that customer perceived value directly does not have a significant effect on e-trust. trusts. From these results it is concluded that the value perceived by Shopee customers cannot affect their trust in Shopee e-commerce itself. Things like this can happen especially with regard to the system of transactions and buying and selling online electronically. The problem of consumer trust in online transactions is still emerging and is still one of the shortcomings that are difficult to obtain. Although users of e-commerce services feel happy to shop online because it is considered easier and more practical to shop and get references related to the products they are looking for and so on, there are still doubts and uncertainties in buying and selling activities online. to customers regarding the information contained in the online shopping site. Some e-commerce users still feel doubtful and unsure of the information that is felt to be unclear and lack of transparency so that the existing information does not match the facts received by the customer. This is one of the shortcomings that are often mentioned in buying and selling online through ecommerce or social media. In this study, it is evidenced from the distribution of respondents' answers which in Table 7 shows that there are $1.22 \%$ of customers who disagree or are not sure and $10.98 \%$ of customers who are hesitant or do not agree with the information on e-commerce sites in accordance with the actual facts, as well as the statement items have the lowest average value of answers with a value of 4.11 when compared to other statements.

\section{The Influence of Customer Perceived Value on E-Loyalty.}

Based on the results of the direct effect hypothesis test for the third hypothesis, it is known that customer perceived value has a significant effect on eloyalty, where the coefficient value is 0.233 with a significant value of $0.000<0.05$, which means that customer perceived value has a significant effect on e-loyalty. Further analysis of the results of research on Shopee customers, it is known that customers feel the benefits and good experiences when shopping, as for example in the emotional value dimension, namely customers feel happy and more comfortable when shopping, then in terms of social value customers can add reference groups and several feel that they can add friendship, then also in terms of price value, customers feel that the price offered is in accordance with the quality and is also cheaper than competitors, and also in terms of performance value, customers find it easier when shopping and getting services as expected, these things are related to customer perceived value can affect customer loyalty to use Shopee services in the future which in turn can have an impact on the success of the company. It is therefore important for companies to understand the perceived and expected value of their customers. Based on the results of research on Shopee customers related to the measurement of the customer perceived value variable as seen in Table 5 , it was found that the lowest statistical calculation value lies in the social value dimension, this means that Shopee needs to pay attention to and further increase the benefits of social values in particular. such 
Dewi Kartika et.al. The Effect of customer perceived value and e-service recovery one-loyalty with esatisfaction and e-trust as intervening variables on e-commerce shopee Indonesia customers in Medan City.

as adding new friendships and adding reference groups that can be felt by customers to help increase customer value and increase customer loyalty for Shopee service users.

\section{Effect of E-Service Recovery on E- Satisfaction.}

Based on the results of the direct effect hypothesis test for the fourth hypothesis, it is known that e-service recovery has a significant effect on esatisfaction, where the coefficient value is 0.281 with a significant value of 0.000 $<0.05$, which means that e-service recovery has a significant effect on e-satisfaction. Further analysis based on the distribution of respondents' answers regarding the service recovery statement carried out by Shopee has a good answer value category, so it can be seen that companies that carry out procedural justice actions such as handling customer complaints properly, providing appropriate decision solutions to customer complaints and responding quickly to complaints customer; besides that, it also performs interactional justice actions such as providing a good explanation to customers regarding service failures that occur, being polite in responding to customer complaints, trying to make maximum efforts to correct errors that occur, and caring for customers; and take good distributive justice actions such as providing solutions according to customer needs and deigning to provide compensation to customers in proportion to the losses suffered. Then it can restore and improve the level of customer satisfaction who had previously been disappointed with the services provided by the company.

\section{Effect of E-Service Recovery on E-Trust.}

Based on the results of the direct effect hypothesis test for hypothesis five, it is known that e-service recovery has a significant effect on e-trust, where the coefficient value is 0.280 with a significant value of $0.000<0.05$, which means that eservice recovery has a significant effect on e-trust. It can be interpreted that if a company performs service recovery actions properly and the information submitted at the time of service recovery is in accordance with the actual facts, it will also have a good impact on the trust of its customers. Further analysis based on the distribution of respondents' answers regarding service recovery carried out by Shopee can be seen from Table 5, it can be concluded that companies that carry out procedural justice actions such as handling customer complaints properly, providing appropriate decision solutions to customer complaints and responding quickly to customer complaints; also take interactional justice actions such as providing a good explanation to customers regarding service failures that occur, being polite in responding to customer complaints and trying their best to correct errors that occur; and carry out good distributive justice actions such as caring for customers, providing solutions according to customer needs and willing to provide compensation to customers in proportion to the losses experienced. So, this can affect customer trust and from these actions they judge that the company is responsible, maintains its integrity and has competence and strives to be able to provide good service to customers.

\section{Effect of E-Service Recovery on E- Loyalty.}

Based on the results of the direct effect hypothesis test for hypothesis six, it is known that e-service recovery has a significant effect on e-loyalty, where the coefficient value is 0.186 with a significant value of $0.000<0.05$, which means that eservice recovery has a significant effect on e-loyalty. In marketing and buying and selling activities both online, mistakes often occur in serving customers, with the occurrence of these errors the company must immediately take action to do good and right things and be generous in pleasing customers with service recovery (e-service recovery) in order to increase loyalty. 
Dewi Kartika et.al. The Effect of customer perceived value and e-service recovery one-loyalty with esatisfaction and e-trust as intervening variables on e-commerce shopee Indonesia customers in Medan City.

customer. Further analysis based on the distribution of respondents' answers regarding service recovery carried out by Shopee seen in Table 5, it can be concluded that companies that carry out procedural justice actions such as handling customer complaints properly, providing appropriate decision solutions to customer complaints and responding quickly to customer complaints. In addition, it also performs interactional justice actions such as providing good explanations to customers regarding service failures that occur, being polite in responding to customer complaints and trying to maximize errors that occur, and carrying out good distributive justice actions such as caring for customers, providing solutions in accordance with customer needs and is willing to provide compensation to customers in proportion to the losses suffered. Then these actions can affect the preferences, support and level of availability of customers to remain loyal to using the company's services in the future.

\section{Effect of E-Satisfaction on E-Trust.}

Based on the results of the direct effect hypothesis test for hypothesis seven, it is known that e-satisfaction has a significant effect on e-trust, where the coefficient value is 0.244 with a significant value of $0.008<0.05$, which means esatisfaction has a significant effect on etrust. Based on these results it can be concluded that customers who are satisfied when shopping will be able to form a customer trust, because in general customers will trust and believe in a company if the customer gets a good experience and is satisfied with the product/service provided. This means that when customers are satisfied with a service, that satisfaction can create confidence that the service/service provider can be trusted. Further analysis regarding the effect of e-satisfaction on etrust on Shopee services can not be separated from what customers feel when using the service as illustrated by the respondents' answers in Table 6 where each statement perceived by the customer is in the good category. This means that the higher the e-satisfaction felt by customers from the convenience dimension where customers feel happy to enjoy online shopping activities using Shopee ecommerce, satisfied because it is easy to find any desired product; then the merchandising dimension where the information provided is relevant to what consumers receive, the product display presented is as expected; then the site design dimensions are happy with the search path that is not complicated, easy and the menu display is neatly arranged; also the security dimension where the confidentiality of personal data is well maintained and transaction security is guaranteed; as well as serviceability dimensions such as free shipping services and promotions provided every month; then this is increasingly playing a role in shaping customer satisfaction so that it affects the level of customer trust in company services, in this case e-commerce Shopee.

\section{Effect of E-Satisfaction on E-Loyalty.}

Based on the results of the direct effect hypothesis test for hypothesis nine, it is known that e-satisfaction has a significant effect on e-loyalty, where the coefficient value is 0.304 with a significant value of $0.000<0.05$, which means e-satisfaction has a significant effect on e-trust. The results of this study based on respondents' answers prove that the higher the customer's esatisfaction is formed from the dimensions, namely convenience where customers feel happy to enjoy online shopping activities and easily find what products they want; then the merchandising dimension where the information provided is quite relevant and the appearance of the product presented is in accordance with the expectations received by consumers; Furthermore, the dimensions of the site design where the search path is not complicated and the menu display is neatly arranged; then the security dimension where the confidentiality of personal data is well maintained and transaction security is guaranteed; as well as 
Dewi Kartika et.al. The Effect of customer perceived value and e-service recovery one-loyalty with esatisfaction and e-trust as intervening variables on e-commerce shopee Indonesia customers in Medan City.

serviceability dimensions such as free shipping services and promotions provided every month; then in the end can make consumers more loyal or further increase customer e-loyalty. E-loyalty is reflected in customer attitudes and behavior such as making online stores the first choice and the best than others, customers are willing to give positive ratings and recommend to others to keep coming back to make purchases at the store and not interested in buying other brands.

\section{The Effect of E-Trust on E-Loyalty.}

Based on the results of the direct effect hypothesis test for hypothesis eight, it is known that e-trust has a significant effect on e-loyalty, where the coefficient value is 0.312 with a significant value of 0.000 $<0.05$, which means that e-satisfaction has a significant effect on e-trust. Further analysis based on the results of research on Shopee customers and respondents' answers illustrates that, companies with good intentions (benevolence) for example are responsible to their customers, accept every customer complaint and accept customer input sincerely; then have an attitude of integrity (integrity) such as providing correct information according to facts and fulfilling agreements made to customers; Furthermore, having competence such as having good knowledge of securing transactions, being able to meet customer needs and being able to provide good service to customers. Then it will be able to form customer trust and can affect customer loyalty to survive using the service in the future, especially for Shopee Indonesia ecommerce users.

\section{The Influence of Customer Perceived Value on E-Loyalty Through E- Satisfaction and E-Trust.}

Based on the results of the effect test for the tenth hypothesis, it is known that the path coefficient value for the indirect effect of the customer perceived value variable on the e-loyalty variable through e-satisfaction and e-trust is 0.028 with a p-value of 0.635
$>$ 0.05. This means that the variable customer perceived value does not indirectly have a significant effect on the eloyalty variable through e-satisfaction and e-trust. While it is different in this study which shows the results that customer perceived value indirectly or through esatisfaction and e-trust simultaneously does not significantly affect e-loyalty. Even if it is seen from the direct influence of customer perceived value it has an effect on e-loyalty. This could be because Shopee e-commerce customers as respondents have expectations from different customer values that they want to get to meet their needs when and or after using this e-commerce service and also have different trust standards, so that esatisfaction is followed e-trust has not been able to provide more value to be able to mediate the relationship between customer perceived value and e-loyalty. This is like the phenomenon that occurs where customers actually feel the benefits of using Shopee e-commerce and enjoy online shopping activities through Shopee ecommerce but customers still do not fully trust the online shopping platform due to the lack of transparency of information presented online so that some the information available is not in accordance with what is received by the customer, for example in the Shopee paylater service which can be seen from customer reviews on the background of the problem and also some product display information presented. This reason is corroborated by the results of respondents' answers to statements related to the information presented by Shoppe which shows a relatively low average value compared to other statements, both from the e-satisfaction variable (in Table 6 the SFT3 statement indicator is happy with the information provided by e-satisfaction). Shopee commerce is relevant to what is accepted by consumers with a mean value of 4.15) and from the e-trust variable (in Table 7 the TR4 statement indicator is sure Shopee provides correct information according to facts with a mean value of 4.11). However, this problem does not rule 
Dewi Kartika et.al. The Effect of customer perceived value and e-service recovery one-loyalty with esatisfaction and e-trust as intervening variables on e-commerce shopee Indonesia customers in Medan City.

out the possibility for them to return to shopping through Shopee e-commerce because there are several other alternative considerations that make them use Shopee and have a good perception of Shopee ecommerce.

\section{Effect of E-Service Recovery on E- Loyalty Through E-Satisfaction and E- Trust.}

Based on the results of the effect test for the eleventh hypothesis, it is known that the path coefficient value for the indirect effect of the e-service recovery variable on the e-loyalty variable through e-satisfaction and e-trus is 0.254 , with a p-value of 0.012 $<0.05$. This means that the e-service recovery variable has a significant indirect effect on the e-loyalty variable through esatisfaction and e-trust. This hypothesis is an update and development research from previous research, where literacy in previous research is still very minimal and difficult to find, especially those who related to online electronic marketing, so that previous research related to this hypothesis in the context of electronic marketing or online transactions is difficult to obtain. However, the results of this study also found that in the electronic context, customer satisfaction (e-satisfaction) and trust (e-trust) were proven to mediate the relationship between electronic service recovery (e-service recovery) and customer loyalty (e-loyalty). Based on this, it can be concluded that both offline (non-electronic) and online or electronically, service companies in particular must take service recovery actions by increasing their attention to factors related to the dimensions of procedural justice, interactional justice, and distributive justice to improve the level of customer satisfaction and be responsible for errors that cause losses to customers so as to restore customer confidence in the performance of the service provider company in this case e-commerce Shopee Indonesia and customers are willing to continue to use their services again in the future.

\section{CONCLUSION}

Based on the results of the analysis and discussion in the previous chapter, the following conclusions can be drawn:

1. Customer Perceived Value has a significant effect on E-Satisfaction on Shopee Indonesia's e-commerce customers.

2. Customer Perceived Value has no significant effect on E-Trust on Shopee Indonesia's e-commerce customers.

3. Customer Perceived Value has a significant effect on E-Loyalty on Shopee Indonesia's e-commerce customers.

4. E-Service Recovery has a significant effect on E-Satisfaction on Shopee Indonesia's e-commerce customers.

5. E-Service Recovery has a significant effect on E-Trust on Shopee Indonesia's e-commerce customers.

6. E-Service Recovery has a significant effect on E-Loyalty for Shopee Indonesia's e-commerce customers.

7. E-Satisfaction has a significant effect on E-Trust on Shopee Indonesia's ecommerce customers.

8. E-Satisfaction has a significant effect on E-Loyalty to Shopee Indonesia's ecommerce customers.

9. E-Trust has a significant effect on ELoyalty on Shopee Indonesia's ecommerce customers.

10. Customer Perceived Value has no significant effect on E-Loyalty through E-Satisfaction and E-Trust on Shopee Indonesia's e-commerce customers.

11. E-Service Recovery has a significant effect on E-Loyalty through ESatisfaction and E-Trust on Shopee Indonesia's e-commerce customers

Acknowledgement: None

Conflict of Interest: None

Source of Funding: None 
Dewi Kartika et.al. The Effect of customer perceived value and e-service recovery one-loyalty with esatisfaction and e-trust as intervening variables on e-commerce shopee Indonesia customers in Medan City.

\section{REFERENCES}

1. Alexander, D. 2014. Analisis Pengaruh Citra Merek dan Kepercayaan Merek terhadap Loyalitas Merek Ades PT. Ades Afindo Putra Setia. Journal Manajemen Petra, Vol. 2, No. 1.

2. Baskara, Isnain Putra dan Guruh Taufan Hariyadi.2014. "Analisis Pengaruh Kepercayaan, Keamanan, Kualitas Pelayanan dan Persepsi akan Resiko terhadap Keputusan Pembelian Melalui Situs Jejaring Sosial” .Universitas Dian Nuswantoro. Semarang.

3. C, K, Laudon., Traver. (2017). E-Commerce 2014, 10th Edition. Pearson Global Edition. Pearson Prentice Hall.

4. Kau, A., \& Loh, E. W. (2006). The effects of service recovery on consumer satisfaction: A comparison between complainants and non-complainants.Journal of Services Marketing, 20(2), 101-111.

5. Kim, H. C., Kim, K. S., \& Shin, J. (2019). The Relationship Between E-Perceived Value, E-Relationship Quality, And ELoyalty. Journal of Theoretical and Applied Information Technology, 97(18), 48114823.

6. Kotler, Philip dan Kevin Keller. 2012. Marketing Management. Edisi ke 14.

7. Lovelock, C. J. (2011). Pemasaran Jasa Manusia Teknologi Strategi Perspektif Indonesia (Jilid Satu Edisi Tujuh). Jakarta: Erlangga.

8. Mencarelli, Rémi \& Arnaud, Rivière. (2012). Towards a Theoretical Clarification of Perceived Value in Marketing. Recherche et Applications en Marketing. 27. 97-122. 10.1177/205157071202700305

9. Oesman, Y.M. (2010). Sukses Mengelola Marketing Mix, CRM, Customer Value, dan
Customer Dependency (Kasus pada Pemasaran Shopping Center). Bandung : Alfabeta.

10. Paramitha, K. A. I., dan Kusuma, A. G. A. A. (2018). Pengaruh Persepsi Kualitas, Citra Merek dan Persepsi Nilai Terhadap Kepuasan untuk Meningkatkan Loyalitas Pelanggan (Studi Pada Produk Laptop Merek Asus). E-Jurnal Manajemen Universitas Udayana, 7(10), 5407-5444. https://doi.org/10.24843/ejmunud.2018.v07. i10.p08.

11. Parasuraman, A Parsu \& Zeithaml, Valarie \& Malhotra, Arvind. (2005). E-S- Qual: A Multiple-Item Scale for Assessing Electronic Service Quality. Journal of Service Research. 7. 213-233. 10.1177/1094670504271156. .

12. Rv, Shabbir. (2017). The Determinants of Loyalty in Online Commerce - An Exploratory Study in India. Electronic Journal of Information Systems in Developing Countries. 81. 1-17. 10.1002/j.1681-4835.2017.tb00599.x.

13. Situmorang, S. H., \& Mulyono, H. (2019). Service Marketing. Medan.

14. Turban. E., King. D., Lee. J. K., Liang, T. P., and Turban, D.C., 2015. Electronic Commerce: A Managerial and Social Networks Perspective. 8th Ed

How to cite this article: Kartika D, Fauzi A, Lubis AN. The Effect of customer perceived value and e-service recovery one-loyalty with esatisfaction and e-trust as intervening variables on e-commerce Shopee Indonesia customers in Medan City. International Journal of Research and Review. 2021; 8(11): 246-258. DOI: https://doi.org/10.52403/ijrr.20211133 